\title{
LA NAISSANCE
}

DU

\section{CHEVALIER AU CYGNE \\ on uss}

\section{ENFANTS CHANGÉS EN CYGNES}

FRENCH POEM OF THE XIITH CENTURY

PUBLISHED FOR THE IRST TIME, TOGETHIR ! wITH Ax INRDTED PROSE VERSIOX, FROY TKE MSS. OF THI KATIONAL AND ARSENAL LUBARIE AT PARIS

WITH INTRODUCTION, NOTESAND VOCABULARY

8y

HENRY ALFRED TODD, Ph. D.

ASSOCIATE IN THE ROMANCE LANGUAGES, JOHXS hOPKINS UNIVERSTY

\section{BALTIMORE}

THE MODERN LANOUAGE A88OOIATION

1889 


\title{
ERNESTO MONACI
}

PROFESSOR IN THE UNIVERSITY OF ROME

\author{
THIS WORK
}

Is

GRATEFULLY INSCRIBED. 


\section{PREFATORY NOTE.}

$T^{O}$ the friendly and unfailing interest of M. Gaston Paris I am a second time indebted for suggestions and encouragement leading to the publication of an inedited Old French text,with the much regretted difference, however, that owing to the force of circumstances it has been necessary in the present case to forego the important benefit of any direct assistance or revision on the part of my former instructors. Apart from this disadvantage, the necessity of bringing the edition within the limits of the publications of the Modern Language Association, has precluded an exhaustive treatment of the numerous subjects rightly considered as belonging to a critical edition. In the Introduction, only a brief sketch could be given of the leading affiliations of the legend involved, with some account of the MSS. employed; while all formal study of the phonetics, morphology, syntax, versification, dialect, etc., of the poem, which should naturally succeed the preliminary constitution of the text, have had to be postponed, in view of what were adjudged, within the purposes of the Modern Language Association, the more practical and immediate claims of Notes and Vocabulary. It is doubtless never, in ordinary conditions, within the power of any single worker to establish in a first edition a wholly accurate and satisfactory text, but I have used my best endeavors to that end, in the hope that even a partial success in the manipulation of material so interesting in itself, may call forth the critical contributions of the best Romance scholars towards its utmost possible improvement.

H. A. T.

Johns Hopkins UnIVBRsity,

Baltimore, Octaber, 1889. 